\title{
FIGHTING ONLINE DEFAMATION, DOXING, AND IMPERSONATION
}

\author{
Ashu M. G. Solo \\ Maverick Trailblazers Inc. ${ }^{\mathrm{TM}}$ \\ Suite 403-A, 1013 Centre Road, Wilmington, DE 19805, USA
}

\begin{abstract}
Online defamation, doxing, and impersonation are three of the major problems of the Internet age. As technology advances, defamation, doxing, and impersonation become greater problems. Online defamation, doxing, and impersonation can cause serious damages to victims. The laws badly need to be updated to deal with defamation, doxing, and impersonation in the information age. This research paper makes 12 recommendations to effectively combat online defamation, doxing, and impersonation in different countries.
\end{abstract}

\section{KEYWORDS}

Defamation, Doxing, Impersonation, Cyberlibel, Libel, Cyberbullying, Fake News, Deepfakes

\section{INTRODUCTION}

This research paper focuses on combating online defamation, doxing, and impersonation (Collins, 2011; Cox, 2014; Koch, 2016; Reznik, 2013). Defamation against an individual involves the communication of false statements that harm the individual's reputation. Doxing of an individual involves the publication of an individual's private information such as his home address or family members.

People can be impersonated for many purposes such as to harm their reputations, to gain personal information on them, to cause them to lose business, to cause them to lose friends, to write exams for them, to vote for them, to spread false information about them, etc.

In the old days, it was hard to spread false information or private information about people. It had to be done by telling people face to face or handing out flyers or something. Only the mainstream media had the means to reach a lot of people. The mainstream media is generally more careful in what it says, although it has crossed the line into defamation many times too, but not anywhere near the extent that people can on the world wide web. Now false information or private information about people can just be posted on the web using a fake name for the world to see (Banerjee \& Chua, 2019; Chiluwa, 2019; Pal \& Banerjee, 2019; Reynard, 2019; Solo, 2019a, 2019b, 2019c). Defamation, doxing, and impersonation on the web are three of the major new problems of the information age.

Social networks like Facebook and Twitter are frequently used to spread defamatory information. New software can be used to detect cyberbullying on social networks (Balakrishnan, Khan, Fernandez, \& Arabnia, 2019). Fake news, which is used to spread disinformation or defamatory information, is a growing problem (Adikpo, 2019; Assay, 2019; Bradshaw \& Howard, 2019; Dale, 2019; Grazulis \& Rogers, 2019; Guadagno \& Guttieri, 2019; Mach, 2019; Rezayi, Balakrishnan, Arabnia, \& Arabnia, 2018; Stengel, 2019; Watts, 2018). Fake news and defamation on the web are frequently used to attack politicians, an unethical type of network politics (Solo \& Bishop, 2011, 2014, 2016, 2017). Deepfakes are videos featuring humans manipulated by computational intelligence. Deepfakes can be used to impersonate individuals while conveying disinformation or defamatory information (Parkin, 2019). The use of deepfakes to impersonate politicians while conveying misinformation is an unethical form of political engineering or computational politics (Solo, 2011, 2014, 2017, 2019d). As technology advances, more sophisticated means can be used to fool people with defamation. The laws need to be updated as recommended in this research paper to stop the spread of defamatory information using social networks, fake news, and deepfakes too. 
Internet defamation, inter alia, severely harms people's reputations; prevents them from getting gainful employment; ruins romantic relationships; causes depression, anxiety, and distress; causes mental health problems, etc. Internet doxing, inter alia, endangers people; causes depression, anxiety, and distress; causes mental health problems; etc. Internet impersonation, inter alia, severely harms people's reputations; prevents them from getting gainful employment; ruins romantic relationships; causes depression, anxiety, and distress; causes mental health problems, etc.

Most private employers these days do web searches on prospective employees to see what turns up. If they have a bunch of people applying for one position, as is usually the case, they aren't going to risk selecting the candidate with a bunch of injurious claims about him on the world wide web whether or not they can determine if it's true.

Humans have a hard time distinguishing between true and false information (Kaufman, 2018; Marsh, Cantor, \& Brashier, 2016; Vosoughi, Roy, \& Aral, 2018). Andrew Butler, an associate professor of psychological and brain sciences at Washington University in St. Louis, said, "Even when people have knowledge that directly contradicts false information, they fail to detect that it is false information (Kaufman, 2018)." Furthermore, humans are predisposed to believing false information. Butler said, "People have a bias to assume truth (Kaufman, 2018)." A research study found that Twitter users are twice as likely to repost fake news as they are to repost real news (Kaufman, 2018; Vosoughi et al., 2018).

The civil remedies for dealing with defamation or doxing are extremely inadequate. Lawyer fees for a defamation or doxing claim in the United States are typically in the range of \$30,000 USD or more. The vast majority of defamation or doxing victims can't afford the legal costs. A civil lawyer with expertise in defamation law said that he got inquiries from a bunch of people defamed on an online hate group, but none could afford to retain him. Most lawyers charge more than this lawyer who has been practicing for a few years. When someone is defamed or doxing on the world wide web, the defamation or doxing typically remains on the Internet until a civil court judgment is obtained and this usually takes years. In the meantime, the victim continues to accumulate all kinds of damages. The author of this research paper has seen people being defamed and doxed on the world wide web contemplate criminal violence as the only means they have to get the defamation and doxing removed.

Freedom of speech was never meant to protect defamation and has never protected defamation. We don't have the right to go around falsely claiming someone is a prostitute or pedophile, but those are the kinds of false statements you regularly see on online hate groups primarily against members of minority groups.

\section{RECOMMENDATIONS TO EFFECTIVELY FIGHT ONLINE DEFAMATION, DOXING, AND IMPERSONATION}

For the reasons above, the laws need to be updated to deal with online defamation, doxing, and impersonation in the information age. Following are 12 recommendations for public policies to effectively combat online defamation, doxing, and impersonation:

1. Criminal laws for defamation need to be enforced. These laws are rarely enforced in the U.S. and Canada.

2. Defamation should be a criminal offense in every country.

3. Impersonation should be a criminal offense in every country.

4. Online posting of a person's home address without permission should be a crime. This leads people with adversaries to fear for the safety of themselves and their families and their property.

5. Small claims courts must be equipped to deal with defamation, doxing, and impersonation lawsuits and must be able to order preliminary and permanent injunctions. Most victims do not have the expertise for pro se legal representation in higher courts and can't afford the costs of lawyers to represent them in higher courts.

6. Every website owner should be required to record the IP addresses of its website users for five years. For each post made on an online forum, the website owner should be required to record the IP address of the individual who made the post and should be required to store this information for five years. This information may be required by law enforcement or people suing for defamation, doxing, or impersonation and must be turned over with search warrants or subpoenas. 
7. No website owner should be able to hide her identity in a domain name registration. Every website owner should be required to provide an address in a domain name registration where he can be served with civil claims, subpoenas, search warrants, etc. for content on the website.

8. A website owner should be liable for defamation, doxing, or impersonation by a website user if the website owner doesn't delete the defamation, doxing, or impersonation after it's complained about by the subject of the defamation, doxing, or impersonation. In the United States, courts have interpreted section 230 of the Communications Decency Act (CDA) to give website owners immunity from defamation by website users (Browne-Barbour, 2015; Communications Decency Act, 1996). In the United Kingdom, under the Defamation Act 2013, a website owner can be liable for defamation by a website user if it isn't deleted after being complained about (Defamation Act 2013, 2013).

9. Search engines should be stopped from indexing and displaying hyperlinks to websites notorious for defamation or doxing. There should also be public pressure on search engine companies to stop indexing and displaying hyperlinks to websites notorious for defamation or doxing.

10. Archiving websites including Google should be stopped from caching or archiving websites notorious for defamation or doxing. There should also be public pressure on archiving website companies to stop caching or archiving websites notorious for defamation or doxing.

11. Search engines should be required to follow injunctions to remove hyperlinks to defamation, doxing, or impersonation on third party websites as well snippets of defamation, doxing, or impersonation on third party websites from search engine return pages.

12. Foreign defamation, doxing, or impersonation judgments must be enforceable in the U.S. It would be impossible for a middle class or poor person in a developing country who is being defamed, doxed, or impersonated on an American website to afford a lawyer in the U.S. to handle a civil claim. People should be able to sue for defamation, doxing, or impersonation in their own countries and get defamation, doxing, or impersonation judgments enforced in the U.S.

\section{CONCLUSION}

Online defamation, doxing, and impersonation are three of the major problems of the computer age. The laws desperately need to be updated and enforced to deal with these problems using the recommendations in this research paper.

Online hate groups use defamation and doxing as a weapon to cyberbully disabled people, particularly people with autism, Muslims, Jews, black people, Hispanics and Latinos, transgendered people, vulnerable people, highly accomplished people, and other minorities. If the laws are updated to prevent online defamation and doxing, online hate groups will no longer be nearly as effective in cyberbullying individuals in minority groups.

\section{REFERENCES}

Adikpo, J. A., 2019. Fake Online News: Rethinking News Credibility for the Changing Media Environment. In I. E. Chiluwa \& S. A. Samoilenko (Eds.), Handbook of Research on Deception, Fake News, and Misinformation Online (pp. 152-166). IGI Global, Hershey, PA. URL: https://www.igi-global.com/chapter/fake-online-news/230752

Assay, B. E., 2019. Social Media and the Challenges of Curtailing the Spread of Fake News in Nigeria. In I. E. Chiluwa \& S. A. Samoilenko (Eds.), Handbook of Research on Deception, Fake News, and Misinformation Online (pp. 226-263). IGI Global, Hershey, PA. URL: https://www.igi-global.com/chapter/social-media-and-the-challengesof-curtailing-the-spread-of-fake-news-in-nigeria/230756

Balakrishnan, V., Khan, S., Fernandez, T., and Arabnia, H. R., 2019. Cyberbullying Detection on Twitter Using Big Five and Dark Triad Features. Elsevier Journal of Personality and Individual Differences (The Official Journal of the International Society for the Study of Individual Differences (ISSID)), 141, 252-257. URL: https://www.sciencedirect.com/science/article/pii/S0191886919300364

Banerjee, S. and Chua, A. Y. K., 2019. Toward a Theoretical Model of Authentic and Fake User-Generated Online Reviews. In I. E. Chiluwa \& S. A. Samoilenko (Eds.), Handbook of Research on Deception, Fake News, and Misinformation Online (pp. 104-120). IGI Global, Hershey, PA. URL: https://www.igi-global.com/chapter/toward-atheoretical-model-of-authentic-and-fake-user-generated-online-reviews/230748 
Bradshaw, S. and Howard, P. N., 2019. The Global Disinformation Order: 2019 Global Inventory of Organised Social Media Manipulation. Computational Propaganda Research Project. Oxford Internet Institute, University of Oxford, Oxford, U.K. URL: https://comprop.oii.ox.ac.uk/wp-content/uploads/sites/93/2019/09/CyberTroop-Report19.pdf

Browne-Barbour, V. S., 2015. Losing Their Licence to Libel: Revisiting § 230 Immunity. Berkeley Technology Law Journal, 30(2), 1505-1560. URL: https://btlj.org/data/articles2015/vol30/30_2/1505-1560_Browne\%20Barbour.pdf

Chiluwa, I. E. and Samoilenko, S. A. (Eds.)., 2019. Handbook of Research on Deception, Fake News, and Misinformation Online. IGI Global, Hershey, PA. URL: https://www.igi-global.com/book/handbook-research-deception-fakenews/218293

Collins, M., 2011. The Law of Defamation and the Internet, Third Edition. Oxford University Press, Oxford, U.K.

$\begin{array}{lllllll}\text { Communications } \quad \text { Decency } & \text { Act, } & \text { United } & \text { States, } & 47 & \text { U.S.C. } \S 230, & \end{array}$ URL: https://uscode.house.gov/view.xhtml?req=communications+decency+act+section+230

Cox, C., 2014. Protecting Victims of Cyberstalking, Cyberharassment, and Online Impersonation through Prosecutions and $\begin{array}{llll}\text { Effective } & \text { Laws. } & \text { Jurimetrics, } & \text { 54(3), }\end{array}$ URL: https://www.jstor.org/stable/24395601?seq=1\#page_scan_tab_contents

Dale, T., 2019. The Fundamental Roles of Technology in the Spread of Fake News. In I. E. Chiluwa \& S. A. Samoilenko (Eds.), Handbook of Research on Deception, Fake News, and Misinformation Online (pp. 122-137). IGI Global, Hershey, PA. URL: https://www.igi-global.com/chapter/the-fundamental-roles-of-technology-in-the-spread-of-fakenews/230750

Defamation Act 2013, United Kingdom, 2013. URL: http://www.legislation.gov.uk/ukpga/2013/26

Grazulis, A. and Rogers, R., 2019. Ridiculous and Untrue-FAKE NEWS!”: The Impact of Labeling Fake News. In I. E. Chiluwa \& S. A. Samoilenko (Eds.), Handbook of Research on Deception, Fake News, and Misinformation Online (pp. 138-151). IGI Global, Hershey, PA. URL: https://www.igi-global.com/chapter/ridiculous-and-untrue--fakenews/230751

Guadagno, R. E. and Guttieri, K., 2019. Fake News and Information Warfare: An Examination of the Political and Psychological Processes from the Digital Sphere to the Real World. In I. E. Chiluwa \& S. A. Samoilenko (Eds.), Handbook of Research on Deception, Fake News, and Misinformation Online (pp. 167-191). IGI Global, Hershey, PA. URL: https://www.igi-global.com/chapter/fake-news-and-information-warfare/230753

Kaufman, M., 2018, March 8. Twitter users are twice as likely to retweet fake news stories than authentic ones. Mashable. URL: https://mashable.com/2018/03/08/twitter-users-retweet-fake-news-study/

Koch, C. M., 2016. To Catch a Catfish: A Statutory Solution for Victims of Online Impersonation. University of Colorado Law Review, $\quad 88(1)$ URL: $\quad$ http://lawreview.colorado.edu/wp-content/uploads/2017/01/12.-88.1Koch_FinalRevised.pdf

Mach, L. T., 2019. The Rise of Professional Facebook Content Generators in Vietnam: A Fake News Campaign against the Betibuti Founder. In I. E. Chiluwa \& S. A. Samoilenko (Eds.), Handbook of Research on Deception, Fake News, and Misinformation Online (pp. 209-225). IGI Global, Hershey, PA. URL: https://www.igi-global.com/chapter/therise-of-professional-facebook-content-generators-in-vietnam/230755

Marsh, E. J., Cantor, A. D., and Brashier, N. M., 2016. Believing that Humans Swallow Spiders in Their Sleep: False Beliefs as Side Effects of the Processes that Support Accurate Knowledge. Psychology of Learning and Motivation, 64, 93-132. URL: https://www.sciencedirect.com/science/article/pii/S0079742115000341

Pal, A. and Banerjee, S. (2019). Understanding Online Falsehood from the Perspective of Social Problem. In I. E. Chiluwa \& S. A. Samoilenko (Eds.), Handbook of Research on Deception, Fake News, and Misinformation Online (pp. 1-17). IGI Global, Hershey, PA. URL: https://www.igi-global.com/chapter/understanding-online-falsehood-from-theperspective-of-social-problem/230742

Parkin, S., 2019, June 22. The rise of the deepfake and the threat to democracy. The Guardian. URL: https://www.theguardian.com/technology/ng-interactive/2019/jun/22/the-rise-of-the-deepfake-and-the-threatto-democracy

Reynard, L. J., 2019. Troll Farm: Anonymity as a Weapon for Online Character Assassination. In I. E. Chiluwa (Ed.), Handbook of Research on Deception, Fake News, and Misinformation Online (pp. 392-419). IGI Global, Hershey, PA. URL: https://www.igi-global.com/chapter/troll-farm/230765

Rezayi, S., Balakrishnan, V., Arabnia, S., and Arabnia, H. R., 2018. Fake News and Cyberbullying in the Modern Era. Proceedings of the International Conference on Computational Science and Computational Intelligence (CSCI 2018). IEEE CPS, Piscataway, NJ.

Reznik, M., 2013. Identity Theft on Social Networking Sites: Developing Issues of Internet Impersonation. Touro Law Review, 29(2), article URL: https://digitalcommons.tourolaw.edu/cgi/viewcontent.cgi?article=1472\&context=lawreview 
Solo, A. M. G. and Bishop, J., 2011. The New Field of Network Politics. Proceedings of the 2011 International Conference on e-Learning, e-Business, Enterprise Information Systems, and e-Government (EEE'11). URL: http://worldcompproceedings.com/proc/p2011/EEE5223.pdf

Solo, A. M. G. and Bishop, J., 2016. Network Politics and the Arab Spring. International Journal of Civic Engagement and Social Change (IJCESC), 3(1), 23-27. URL: http://www.igi-global.com/article/network-politics-and-the-arabspring/149855

Solo, A. M. G. and Bishop, J., 2017. Conceptualizing Network Politics following the Arab Spring: An African Perspective. In J. Bishop (Ed.), The Digital Media Reader (pp. 205-212). Crocels Press, Wilmington, DE.

Solo, A. M. G., \& Bishop, J., 2014. Conceptualizing Network Politics following the Arab Spring. In A. M. G. Solo (Ed.), Handbook of Research on Political Activism in the Information Age (pp. 231-239). IGI Global, Hershey, PA. URL: http://www.igi-global.com/chapter/conceptualizing-network-politics-following-the-arab-spring/110681

Solo, A. M. G., 2011. The New Fields of Public Policy Engineering, Political Engineering, Computational Public Policy, and Computational Politics. Proceedings of the 2011 International Conference on e-Learning, e-Business, Enterprise Information Systems, and e-Government (EEE'11). URL: http://worldcompproceedings.com/proc/p2011/EEE5211.pdf

Solo, A. M. G., 2014. The New Interdisciplinary Fields of Political Engineering and Computational Politics. In A. M. G. Solo (Ed.), Political Campaigning in the Information Age (pp. 226-232). IGI Global, Hershey, PA. URL: $\quad$ https://www.igi-global.com/chapter/the-new-interdisciplinary-fields-of-political-engineering-andcomputational-politics/109123

Solo, A. M. G., 2017. An Overview of the New Interdisciplinary Fields of Political Engineering and Computational Politics for the Next Frontier in Politics. Proceedings of the 2017 International Conference on Computational Science and Computational Intelligence (CSCI'17). URL: https://ieeexplore.iee.org/document/8561084

Solo, A. M. G., 2019a. Brief on Effectively Combatting Cyberbullying and Cyberlibel by Online Hate Groups for the Study on Online Hate of the Standing Committee on Justice and Human Rights for the House of Commons of Canada. Standing Committee on Justice and Human Rights, House of Commons of Canada. URL: https://www.ourcommons.ca/Content/Committee/421/JUST/Brief/BR10520155/br-external/SoloAMG-e.pdf

Solo, A. M. G., 2019b. Mémoire sur la lutte efficace contre les actes de cyberintimidation et de diffamation en ligne commis par des groupes haineux présenté au Comité permanent de la justice et des droits de la personne de la Chambre des communes du Canada dans le cadre de son étude sur la haine en ligne. Standing Committee on Justice and Human Rights, House of Commons $\quad$ of $\quad$ Canada. URL: $\quad$ https://www.noscommunes.ca/Content/Committee/421/JUST/Brief/BR10520155/br-external/SoloAMG10061182-f.pdf

Solo, A. M. G., 2019c. Combating Online Defamation and Doxing in the United States. Proceedings of the 2019 International Conference on Internet Computing and Internet of Things (ICOMP'19). URL: https://csce.ucmss.com/cr/books/2019/LFS/CSREA2019/ICM3560.pdf

Solo, A. M. G., 2019d. The Interdisciplinary Fields of Political Engineering, Public Policy Engineering, Computational Politics, and Computational Public Policy. In A. M. G. Solo (Ed.), Handbook of Research on Politics in the Computer Age. IGI Global, Hershey, PA. URL: https://www.igi-global.com/book/handbook-research-politics-computerage/228093

Stengel, R., 2019. Information Wars: How We Lost the Global Battle Against Disinformation and What We Can Do About It. Grove Press, New York.

Vosoughi, S., Roy, D., and Aral, S., 2018. The spread of true and false news online. Science, 359(6380), 1146-1151. URL: https://science.sciencemag.org/content/359/6380/1146

Watts, C., 2018. Messing with the Enemy: Surviving in a Social Media World of Hackers, Terrorists, Russians, and Fake News. Harper, New York. 